\title{
The Use of Video as a Learning Strategy in Supporting the Increasing Knowledge and Clinical Skills of Nursing Students
}

\author{
Indah Permata Sari ${ }^{1,2}$, Sri Sundari ${ }^{3}$
}

1 Program Studi Magister Keperawatan, Program Pascasarjana, Universitas Muhammadiyah Yogyakarta

2 Program Studi Ilmu Keperawatan, Sekolah Tinggi Ilmu Kesehatan Citra Delima Bangka Belitung

3 Program Studi Pendidikan Dokter, Fakultas Kedokteran dan Ilmu Kesehatan, Universitas Muhammadiyah Yogyakarta

\section{Article Info}

Article History:
Submitted: July $18^{\text {th }}, 2020$
Accepted: Jan $4^{\text {th }}, 2021$
Published: Feb $13^{\text {th }}, 2021$
Keywords:
Videos; Knowledge; Clinical
skills; Nursing student

skills; Nursing student

\begin{abstract}
Video is a promising, relevant, and increasingly used form of learning media that can improve the quality of education. This study aims to further examine the use of video as a learning strategy in supporting the knowledge and clinical skills of nursing students. This study uses a quasi-experiment with pretest and posttest design to compare video methods and lecture methods in nursing students. The research sample population was 60 respondents and the research data collection method used the MCQ (Multiple Choice Question) questionnaire sheet for the assessment of the knowledge, while the OSCE (Objective Structured Clinical Examination) sheet for the assessment of students' clinical skills. Based on the results of research using paired t-test, posttest t-test, and hypothesis testing using independent sample $t$-test that the value of $t$ count $>t$ table ( $p$-value $=0,000<0.05$ ), so that the value is significant in improving both aspects of the assessment. The video method has a higher average score and improvement than the lecture method.
\end{abstract}

\section{PENDAHULUAN}

Perkembangan teknologi sangat berpengaruh dalam kehidupan sehari-hari termasuk dalam dunia kesehatan sehingga menyebabkan perubahan besar dalam praktik dan pendidikan keperawatan [1]. Pendidikan keperawatan saat ini dituntut harus memiliki standar metode pembelajaran yang tepat supaya dapat diterima untuk peningkatan keterampilan klinis dalam mencapai efektifitas pembelajaran [2]. Metode pembelajaran yang tepat dapat membantu kebutuhan individu mahasiswa keperawatan dengan menawarkan kombinasi pedagogi pada pendekatan pendidikan yang menggabungkan metode konvensional dengan metode berbasis online [3].

Pemilihan metode yang tepat dapat memberikan peluang dalam penyampaian informasi secara sinkron dalam proses pembelajaran [4]. Pengembangan keterampilan psikomotorik dan pemikiran kritis dapat ditingkatkan melalui metode pendidikan aktif seperti simulasi dan penerapan video pembelajaran [5].

Corresponding author:

Indah Permata Sari

indah.nedu@gmail.com

Media Keperawatan Indonesia, Vol 4 No 1, February 2021

e-ISSN: 2615-1669

ISSN: 2722-2802

DOI: $\underline{10.26714 / \mathrm{mki} .4 .1 .2021 .47-55}$ 
Pengetahuan dan keterampilan professional itu tentu menjadi dasar dalam pendidikan keperawatan [6]. Nilai pendidikan umumnya diukur dalam hal hasil kinerja untuk aspek pengetahuan, keterampilan ataupun sikap [7].

Video merupakan salah satu media dalam proses pembelajaran yang efektif dikarenakan dapat menunjukkan keterampilan dan aktivitas secara nyata, mengurangi pembiayaan dalam presentasi serta penggunaan yang dapat diulang. Penggunaan video dalam proses pembelajaran dapat membantu pengembangan keterampilan klinis psikomotorik mahasiswa [8], dan juga meningkatkan kepercayaan diri mahasiswa [9]. Penggunaan video dalam sesi pengajaran pada bidang keperawatan dapat membantu mahasiswa mengidentifikasi teknik komunikasi yang efektif dan untuk merangsang diskusi sebagai tolak ukur komunikasi [10]. Umumnya mahasiswa keperawatan memiliki tingkat kepercayaan diri yang lebih tinggi dengan keterampilan mereka, mereka lebih cenderung mengidentifikasi keterampilan ini sebagai hal yang penting dalam keperawatan dan memiliki kemauan yang lebih besar untuk menerapkannya [11].

Video pembelajaran secara umum memberikan efek positif pada keterampilan komunikasi dan motivasi belajar di kalangan mahasiswa keperawatan [12]. Hasil temuan menunjukkan bahwa kelompok eksperimen dengan menggunakan video menunjukkan peningkatan keterampilan komunikasi yang lebih tinggi dan motivasi belajar yang lebih kuat daripada kelompok kontrol. Penerapan strategi pengajaran melalui video umpan balik dapat meningkatkan komunikasi generik dan keterampilan praktik. Selain itu, menemukan perawat yang menerima umpan balik video tampaknya lebih memperhatikan permintaan pasien untuk bantuan dan pemeriksaan fisik mereka [13]. Video keterampilan juga dapat menunjukkan jenis interaksi yang perlu terjadi antara pasien dan perawat untuk menciptakan hubungan saling percaya dan perhatian [14].

Berdasarkan hal tersebut, maka penerapan video pembelajaran dapat diterapkan pada mahasiswa Program Studi S1 Keperawatan di Sekolah Tinggi Ilmu Kesehatan Citra Delima Bangka Belitung. Pemilihan tempat penelitian ini didasari atas observasi keterampilan mahasiswa yang ada saat ini masih sangat kurang dikarenakan penerapan metode yang diajarkan belum optimal dan masih menerapkan metode konvensional. Oleh karena itu, penelitian ini bertujuan untuk mengkaji lebih lanjut mengenai penggunaan video sebagai strategi pembelajaran dalam mendukung pengetahuan dan keterampilan klinis mahasiswa keperawatan.

\section{METODE}

Penelitian ini menggunakan desain penelitian kuantitatif melalui pendekatan quasi experiment dengan rancangan pretest dan posttest with control group untuk membandingkan metode video dan metode ceramah atau konvensional pada mahasiswa keperawatan. Pada penelitian ini yang menjadi variabel bebas berupa video pembelajaran, sedangkan variabel terikat pada penelitian ini yaitu: pengetahuan dan keterampilan klinis pada mahasiswa keperawatan. Pemilihan sampel dilakukan menggunakan simple random sampling. Responden dalam penelitian ini adalah 60 orang mahasiswa semester tiga (3) yang terbagi pada kelompok intervensi sebanyak 30 orang mahasiswa dan kelompok kontrol sebanyak 30 mahasiswa. Penelitian dilaksanakan di Sekolah Tinggi Ilmu Kesehatan Citra Delima Bangka Belitung yang bertempat di Kota Pangkalpinang, Provinsi Kepulauan Bangka Belitung pada bulan Januari sampai dengan April 2020.

Instrumen penelitian ini berupa video dan lembar penilaian keterampilan klinis pemasangan infus dan perawatan luka 
bersih. Tahapan penelitian ini terlebih dahulu dilakukan pembuatan video dengan bantuan ahli media dan tenaga pendidik, dan pembuatan kuesioner. Kuesioner yang digunakan dalam penelitian ini yaitu kuesioner yang telah dilakukan uji validitas dan reabilitas sebelumnya. Pengumpulan data penelitian mengenai penilaian pengetahuan mahasiswa keperawatan menggunakan lembar kuesioner MCQ (Multiple Choice Question), sedangkan penilaian keterampilan klinis mahasiswa menggunakan lembar OSCE (Objective Structured Clinical Examination). Penelitian ini dilakukan dengan tiga (3) teknik analisis data, yaitu: uji normalitas dan homogenitas data; persentase perolehan skor; dan uji koefisiensi korelasi. Penelitian ini dapat terlaksana setelah dinyatakan laik etik (ethical clereance) dengan No. 1001/KEPUNISA/I/2020 yang telah dilakukan oleh Komisi Etik Penelitian Kesehatan (Health Research Committee) Universitas Aisyiyah Yogyakarta.

\section{HASIL}

Berdasarkan hasil penelitian seperti yang tersaji pada Tabel 1, menunjukkan bahwa hasil pre-test (sebelum intervensi) pada indikator tingkat pengetahuan pemasangan infus dan pengetahuan perawatan luka bersih kelas intervensi dan kontrol mempunyai nilai rata-rata $\leq 61$, yang artinya pengetahuan mahasiswa masih sangat rendah dan masuk kategori kurang. Hal ini berbeda dengan nilai post-test (setelah intervensi), dimana pada kelas perlakuan (kelompok intervensi) yang menggunakan video pembelajaran memiliki nilai rata-rata sangat baik apabila dibandingkan dengan kelompok kontrol yang hanya menggunakan metode ceramah atau konvensional. Hasil $p$-value pada kedua aspek pengetahuan ini yaitu $p$-value $(0,000$ $<0,05$ ). Hasil tersebut dapat disimpulkan bahwa terjadinya peningkatan secara signifikan pada skor hasil pengetahuan mahasiswa pada kelas kontrol masih rendah apabila dibandingkan dengan kelas intervensi.
Hasil keterampilan klinis mahasiswa pada (Tabel 2), menunjukkan bahwa hasil pretest (sebelum intervensi) keterampilan klinis mahasiswa tentang pemasangan infus dan perawatan luka bersih kelas intervensi maupun kontrol mempunyai nilai rata-rata $\leq 61$ yang masuk dalam kategori masih sangat rendah dan kurang. Hasil post-test (sesudah intervensi) kelas intervensi mengalami peningkatan yang sangat signifikan dibandingkan dengan kelas kontrol. Hal ini mengindikasikan bahwa kurangnya tingkat keterampilan dasar yang dimiliki mahasiswa diakibatkan kurangnya pengetahuan dan kurangnya optimalnya metode yang ada saat ini dalam mendukung keterampilan klinis mahasiswa keperawatan. Hasil p-value pada kedua aspek keterampilan klinis ini yaitu $(0,000<$ $0,05)$, yang bahwa terjadinya peningkatan secara signifikan pada kedua kelompok dalam hal keterampilan klinis mahasiswa.

Berdasarkan hasil analisis dengan menggunakan uji t post-test (Tabel 3), diketahui bahwa rata-rata kenaikan pengetahuan dan keterampilan mahasiswa baik pada pemasangan infus maupun perawatan luka bersih pada kisaran 71,68 sampai dengan 75,86. Pada kelas kontrol kenaikan kelas pada aspek pengetahuan dan keterampilan klinis mahasiswa mengenai pemasangan infus maupun perawatan luka bersih yaitu pada kisaran 18,95 sampai dengan 28,41, sehingga diketahui kenaikan skor hasil pengetahuan dan keterampilan klinis mahasiswa kelas intervensi lebih besar dibandingakn dengan kelas kontrol. Hasil nilai $t$ hitung $>\mathrm{t}$ tabel dengan nilai signifikansinya kurang dari $0,05(\mathrm{p}=0,000<0,05)$, sehingga hasil penelitian ini dapat dinyatakan terdapat perbedaan secara signifikan dalam peningkatan skor hasil pengetahuan maupun keterampilan klinis mahasiswa keperawatan. Metode video memiliki ratarata dan peningkatan skor lebih tinggi dibandingkan metode ceramah dikarenakan metode berbasis video dapat memfasilitasi dalam proses mendapatkan informasi yang lebih cepat, dapat 
mempertahankan pengetahuan serta mengingatnya dengan lebih akurat, sedangkan metode ceramah hanya terfokus pada penjelasan dosen atau tenaga pendidik sedangkan untuk mahasiswanya sendiri kurang aktif dalam pembelajaran.

Tabel 1

Perbedaan aspek pengetahuan mahasiswa

\begin{tabular}{|c|c|c|}
\hline \multicolumn{1}{|c|}{ Indikator } & $\begin{array}{c}\text { Kelompok } \\
\text { intervensi }\end{array}$ & $\begin{array}{c}\text { Kelompok } \\
\text { kontrol }\end{array}$ \\
\hline Rerata pengetahuan pemasangan infus sebelum intervensi & $56,48 \pm 9,56$ & $51,11 \pm 10,97$ \\
\hline Rerata pengetahuan pemasangan infus setelah intervensi & $88,26 \pm 8,18$ & $63,51 \pm 6,65$ \\
\hline$p$ & \multicolumn{2}{|c|}{0,0001} \\
\hline Rerata pengetahuan perawatan luka bersih sebelum intervensi & $57,12 \pm 8,42$ & $54,55 \pm 10,88$ \\
\hline Rerata pengetahuan perawatan luka bersih setelah intervensi & $89,34 \pm 6,68$ & $64,56 \pm 6,93$ \\
\hline$p$ & \multicolumn{2}{|c|}{0,0001} \\
\hline
\end{tabular}

Tabel 2

Perbedaan aspek keterampilan klinis mahasiswa

\begin{tabular}{|c|c|c|}
\hline \multicolumn{1}{|c|}{ Indikator } & $\begin{array}{c}\text { Kelompok } \\
\text { intervensi }\end{array}$ & \multicolumn{1}{|c|}{$\begin{array}{c}\text { Kelompok } \\
\text { kontrol }\end{array}$} \\
\hline Rerata keterampilan klinis pemasangan infus sebelum intervensi & $51,97 \pm 10,07$ & $47,64 \pm 8,98$ \\
\hline Rerata keterampilan klinis pemasangan infus setelah intervensi & $91,03 \pm 5,49$ & $65,43 \pm 7,62$ \\
\hline p & \multicolumn{2}{|c|}{0,0001} \\
\hline $\begin{array}{c}\text { Rerata keterampilan klinis perawatan luka bersih setelah } \\
\text { intervensi }\end{array}$ & $92,47 \pm 5,74$ & $64,75 \pm 6,46$ \\
\hline$p$ & 0,0001 \\
\hline
\end{tabular}

Tabel 3

Perbedaan rerata pengetahuan dan keterampilan antara kelompok intervensi dan kelompok kontrol

\begin{tabular}{|c|c|c|c|}
\hline Indikator & $\begin{array}{l}\text { Kelompok } \\
\text { intervensi }\end{array}$ & $\begin{array}{c}\text { Kelompok } \\
\text { kontrol }\end{array}$ & $p$ \\
\hline Rerata pengetahuan pemasangan infus & $88,263 \pm 8,181$ & $63,510 \pm 6,659$ & \multirow{2}{*}{$0,000^{*}$} \\
\hline Rerata pengetahuan perawatan luka bersih & $89,336 \pm 6,682$ & $64,560 \pm 6,935$ & \\
\hline Rerata keterampilan klinis pemasangan infus & $87,376 \pm 7,536$ & $63,510 \pm 6,659$ & \multirow{2}{*}{$0,000^{*}$} \\
\hline Rerata keterampilan klinis perawatan luka bersih & $89,120 \pm 6,175$ & $64,560 \pm 6,935$ & \\
\hline
\end{tabular}

* Independent t-test

\section{PEMBAHASAN}

\section{Pengetahuan Mahasiswa Keperawatan}

Hasil penelitian ini diketahui bahwa jenjang kemampuan mahasiswa keperawatan di STIKes Citra Delima Bangka Belitung yaitu pada jenjang C4 (analisis), dimana mahasiswa memiliki kemampuan untuk merinci dan menguraikan suatu faktor yang menjadi penyebab dan memahami antar faktor lainnya. Kemampuan tingkat pengetahuan awal mahasiswa kelas intervensi masih rendah hal ini menjadi salah satu kelemahan dalam penelitian dikarenakan mahasiswa belum memahami dan mempelajari materi yang diujikan. Hasil pengetahuan mahasiswa mengalami peningkatan secara signifikan setelah dengan adanya penerapan video sebagai media pembelajaran. Selain itu, media pembelajaran yang diterapkan ini tentu juga dapat memberikan semangat tersendiri bagi mahasiswa dan dapat menciptakan pembelajaran yang menyenangkan sehingga tentunya akan tercapai tujuan pembelajaran tersebut [12]. 
Penggunaan video sebagai media pembelajaran dalam dunia pendidikan khususnya dibidang keperawatan tentu sangat berguna dalam menyajikan informasi baru. Selain itu juga untuk memperkuat pembelajaran sebelumnya dalam mendalami materi yang ada [15]. Video pembelajaran juga dapat dianggap sebagai sarana ringkas untuk memberikan informasi klinis kepada sejumlah besar penyedia layanan kesehatan [16].

Video pembelajaran sebagai salah satu media pembelajaran yang efektif apabila dibandingkan metode konvensional seperti ceramah. Hal ini sesuai dengan hasil penelitian yang dilakukan dimana apabila dilakukan secara terus menerus akan menimbulkan kejenuhan terhadap mahasiswa pada umumnya tidak terkecuali mahasiswa keperawatan untuk mencapai tujuan pembelajaran dalam meningkatkan pengetahuannya. Menurut studi lain metode ceramah sebagai bentuk metode tradisional yang hanya berpusat pada pengajar dalam merancang kegiatan pendidikan dan mahasiswa sebagai peserta didik pada umumnya kurang aktif [17].

Metode konvensional dianggap kurang tepat dalam meningkatkan pengetahuan dan keterampilan klinis mahasiswa pada tingkat pembelajaran yang lebih tinggi [18]. Keuntungan dari metode konvensional seperti ceramah ini tentu hanya dapat melatih sebagian besar orang dalam periode waktu tertentu saja dan tidak dapat dilakukan secara berlulang-ulang, sehingga apabila ingin mendalami atau meningkatkan pengetahuan tentu memerlukan waktu yang lebih lagi [19].

\section{Keterampilan Klinis Mahasiswa Keperawatan}

Capaian pembelajaran Program Studi S1 Keperawatan (KKNI Level 6), didapatkan dari hasil penelitian menunjukkan bahwa mahasiswa di STIKes Citra Delima Bangka Belitung memiliki pengetahuan pada keterampilan klinis pada tingkatan menguasai teknik, prinsip dan prosedur pelaksanaan asuhan dan praktik keperawatan pada bidang keilmuan keperawatan dasar. Selain itu, keterampilan khusus yang didapatkan mahasiswa yaitu mahasiswa mampu mengaplikasikan asuhan keperawatan sesuai standar asuhan keperawatan dan kode etik perawat; menguasai teknik keselamatan pasien (patient safety) dan mampu melaksanakan prosedur penanganan bantuan hidup dasar (basic life support).

Metode penilaian yang didapatkan pada hasil penelitian ini dengan menggunakan rekaman video untuk menilai keterampilan klinis mahasiswa adalah salah satu metode yang tepat. Hal ini didukung dengan hasil evaluasi bahwa metode pembelajaran ini dapat memuaskan mahasiswa dan bersifat fleksibilitas dan kesempatan untuk pengulangan dalam mendalaminya [20], dan dapat membantu menurunkan tingkat kecemasan mahasiswa dalam memahami maksud yang ingin dicapai [21]. Metode elektronik memiliki dampak positif pada pendidikan dan efek ini jauh lebih efektif ketika menggunakan video [22].

Pengembangan keterampilan klinis ini perlu dilakukan di lingkungan perguruan tinggi tentu untuk mempersiapkan mahasiswa untuk pengalaman dunia nyata. Keterampilan klinis dapat merujuk pada pemeriksaan fisik, prosedur praktis, dan keterampilan psikomotor seperti yang dilakukan oleh seorang perawat [23,24]. Selain keterampilan psikomotorik, mahasiswa tentu juga harus mendapatkan keterampilan seperti berpikir kritis, pemecahan masalah, dan pengambilan keputusan sebagai bentuk dari tujuan utama daalam praktik pelatihan klinis [25].

Metode konvensional pada mahasiswa keperawatan pada umumnya tanpa peningkatan pengetahuan atau keterampilan yang konsisten atau tidak dapat diulang [26]. Metode ini hanya memberikan mahasiswamelalui pengetahuan teoritis dan etika dasar yang 
dapat digunakan untuk memperluas ruang lingkup keperawatan, pemahaman mereka tentang pasien, dan pendekatan yang diperlukan untuk menyelesaikan masalah yang berhubungan dengan kesehatan pasien saja [27].

Hasil nilai dari keterampilan klinis tersebut dapat dipengaruhi oleh keyakinan dari mahasiswa itu sendiri. Keyakinan sering juga dikatakan sebagai tindakan atau perilaku sebagai hasil dari pengetahuan dan keterampilan klinis seseorang, serta dianggap sebagai indikator penting. Bukti menunjukkan bahwa, meskipun pengukuran kompetensi klinis keterampilan bersifat positif dan obyektif, namun masih ada mahasiswa keperawatan umumnya merasa bahwa mereka kurang percaya diri, yang mempengaruhi kemampuan mereka untuk menyelesaikan tugas secara efektif [28].

Berdasarkan hasil penelitian tersebut diketahui bahwa skor untuk pengetahuan dan keterampilan klinis pada kelompok intervensi lebih tinggi dibandingkan kelompok kontrol, walaupun secara statistik tidak ada perbedaan yang signifikan Kelompok intervensi, bagaimanapun, memiliki skor yang secara signifikan lebih tinggi untuk motivasi belajar, kepercayaan diri dalam praktik, dan kepuasan kelas dibandingkan dengan kelompok kontrol. Ada korelasi positif untuk motivasi belajar dan kepercayaan diri dalam praktik keterampilan klinis mahaiswa. Penggunaan metode pendidikan modern seperti halnya video pembelajaran sangat penting sehingga beberapa pakar pendidikan lebih mementingkan pemilihan metode pengajaran yang tepat dalam upaya meningkatakan pengetahuan dan keterampilan.

Metode penilaian yang didapatkan pada hasil penelitian ini dengan menggunakan rekaman video untuk menilai keterampilan klinis mahasiswa adalah salah satu metode yang tepat. Hal ini didukung dengan hasil evaluasi bahwa metode pembelajaran ini dapat memuaskan mahasiswa dan bersifat fleksibilitas dan kesempatan untuk pengulangan dalam mendalaminya [20]. Selain itu, juga dapat membantu menurunkan tingkat kecemasan mahasiswa dalam memahami maksud yang ingin dicapai [21]. Metode elektronik memiliki dampak positif pada pendidikan dan efek ini jauh lebih efektif ketika menggunakan video [22].

\section{Perbedaan Pengetahuan dan Keterampilan Klinis Mahasiswa Keperawatan}

Berdasarkan hasil didapatkan bahwa
terbukti metode video mampu
meningkatkan pengetahuan ran
keterampilan dibandingkan dengan metode ceramah atau konvensional. Hasil tersebut didukung dengan nilai signifikansinya kurang dari $0,05(\mathrm{p}=0,000<0,05)$, sehingga nilai tersebut signifikan dalam meningkatkan kedua aspek penilaian tersebut. Metode video mempunyai skor lebih tinggi dibandingkan metode ceramah dikarenakan metode berbasis video dapat memfasilitasi dalam proses mendapatkan informasi yang lebih cepat, dapat mempertahankan pengetahuan serta mengingatnya dengan lebih akurat, sedangkan metode ceramah hanya terfokus pada penjelasan dosen atau tenaga pendidik sedangkan untuk mahasiswanya sendiri kurang aktif dalam sistem pembelajaran yang ada.

Penggunaan video sebagai salah satu metode pembelajaran yang baik karena secara substansial dapat meningkatkan kuantitas dan kualitas waktu yang dihabiskan untuk suatu pembelajaran. Penggunaan video juga dapat memperkaya kurikulum pendidikan di berbagai bidang pengajaran yang berbasispada sains maupun bidang kesehatan [29]. Penggunaan metode ceramah akan mengalami kesulitan dalam melakukan peningkatan keterampilan klinis karena kurangnya paparan dan praktik selama 
program sarjana keperawatan mereka [30]. Selain itu, pengetahuan dan kepercayaan juga sangat diperlukan dan penilaian klinis untuk menerapkan konsep yang dipelajari sebagai mahasiswa keperawatan [31].

\section{Gaya Belajar Mahasiswa Keperawatan di STIKes Citra Delima Bangka Belitung}

Berdasarkan hasil penelitian diketahui bahwa gaya belajar mahasiswa keperawatan di STIKes Citra Delima lebih ke auditori atau visual saja yaitu hanya mendengarkan dan melihat tenaga pendidik atau dosen dalam menjelaskan setiap materi. Gaya belajar visual misalnya hanya melihat gambar, grafik, video, dan grafik, sedangkan gaya belajar audiotori dengan mendengarkan ceramah, diskusi, dan berbicara. Hal ini sesuai dengan nilai pretest pada pengetahuan dan keterampilan klinis pemasangan infus dan perawatan luka bersih yang masih kurang. Sehingga gaya belajar seperti ini kurang tepat dalam proses meningkatkan pengetahuan mahasiswa. Gaya belajar mahasiswa tentu harus memungkinkan tenaga pendidik untuk memilih teknik pengajaran yang benar. Salah satu kesulitan utama yang dihadapi tenaga pendidik pada perguruan tinggi adalah untuk memahami bagaimana meningkatkan prestasi akademik dengan menggabungkan teknik pengajaran dan gaya belajar mahasiswa [32]. Metode video pembelajaran dapat dijadikan alternatif dalam kurikulum pendidikan keperawatan. Hal ini menunjukkan bahwa metode pengajaran ini cocok dengan berbagai gaya belajar dan tampaknya lebih efektif dengan masing-masing mahasiswa.

Tren terbaru pada pembelajaran yang berpusat pada mahasiswa perlu diterapkan di STIKes Citra Delima dengan gaya belajar yang tepat dalam memberikan pemahaman bagaimana mahasiswa keperawatan memperoleh dan memproses informasi. Setiap mahasiswa tentu memiliki cara belajar yang berbeda, memahami kelemahan dan kekuatan mereka dalam hal ini akan membantu merancang teknik pengajaran yang tepat [33]. Pemilihan gaya belajar yang tepat akan membantu memfasilitasi mahasiswa untuk berpikir, memprioritaskan, merancang, memahami, memvisualisasikan, mengingat, membuat asosiasi yang sesuai, dan menyelesaikan suatu masalah.

\section{SIMPULAN}

Penelitian ini menunjukkan bahwa secara perspektif penggunaan video pembelajaran dapat berfungsi secara efektif dan efisien sebagai salah satu alat media pembelajaran untuk mencapai tujuan dalam meningkatkan pengetahuan dan keterampilan klinis mahasiswa keperawatan dibandingkan dengan metode konvensional atau metode ceramah. Perlunya kajian lanjutan mengenai metode pembelajaran lainnya yang efektif dalam peningkatan pengetahuan dan keterampilan klinis mahasiswa keperawatan, sehingga dapat dikolaborasikan dan disempurnakan dalam mencapai tujuan dari pembelajaran tersebut.

\section{UCAPAN TERIMAKASIH}

Penulis mengucapkan terimakasih kepada responden dan semua pihak yang telah membantu dan mendukung dalam proses penelitian dan penulisan artikel penelitian ini.

\section{REFERENSI}

[1] Park M, Kjervik D, Crandell J, Oerman MH. The relationship of ethics education to moral sensitivity and moral reasoning skill of nursing student. Nurs Ethics 2012;19:568-80.

[2] Sari IP, Sundari S. Penerapan Video Pembelajaran dapat Meningkatkan Keterampilan Klinis dalam Pendidikan Keperawatan: A Literature Review. J Pendidik Keperawatan Indones 2019;5:34-41. https://doi.org/10.17509/jpki.v5i1.15128.

[3] Park JY, Woo CH, Yoo JY. Effects of Blended Cardiopulmonary Resuscitation and Defibrillation E-learning on Nursing Students' 
Self-efficacy, Problem Solving, and Psychomotor Skills. CIN - Comput Informatics Nurs 2016;34:272-80. https://doi.org/10.1097/CIN.0000000000000 227.

[4] Kaur M. Blended Learning - Its Challenges and Future. Procedia - Soc Behav Sci 2013;93:6127.

https://doi.org/10.1016/j.sbspro.2013.09.248.

[5] Mould J, White H, Gallagher R. Evaluation of a critical care simulation series for undergraduate nursing students. Contemp Nurse 2011;38:180-90. https://doi.org/10.5172/conu.2011.38.12.180 .

[6] Catlett S, Lovan SR. Being a good nurse and doing the right thing: A replication study. Nurs Ethics 2011;18:54-63. https://doi.org/10.1177/0969733010386162.

[7] Graafland M, Dankbaar M, Mert A, Lagro J, De Wit-Zuurendonk L, Schuit S, et al. How to Systematically Assess Serious Games Applied to Health Care. JMIR Serious Games 2014;2:1-8. https://doi.org/10.2196/games.3825.

[8] Holland A, Smith F, Mccrossan G, Adamson E, Watt S, Penny K. Nurse Education Today Online video in clinical skills education of oral medication administration for undergraduate student nurses: A mixed methods, prospective cohort study. Nurse Educ Pract 2013;33:66370.

https://doi.org/10.1016/j.nedt.2012.01.006.

[9] Wright C, Hogard E, Ellis R, Smith D, Kelly C. Effect of PETTLEP imagery training on performance of nursing skills: Pilot study. J Adv Nurs https://doi.org/10.1111/j.13652648.2008.04706.x.

[10] Lynch K, Barr N, Oprescu F. Learning paramedic science skills from a first person point of view: An initial investigation. Proc Eur Conf eGovernment, ECEG 2012;10:284-93.

[11] Hibbert EJ, Lambert T, Carter JN, Learoyd DL, Twigg S, Clarke S. A randomized controlled pilot trial comparing the impact of access to clinical endocrinology video demonstrations with access to usual revision resources on medical student performance of clinical endocrinology skills. BMC Med Educ 2013;13:1-10.

[12] Yoo MS, Chae S-M. Effects of Peer Review on Communication Skills and Learning Motivation Among Nursing Students. J Nurs Educ 2011;50:230-3.

https://doi.org/10.3928/0148483420110131-03.

[13] Noordman J, van der Weijden T, van Dulmen S.
Effects of video-feedback on the communication, clinical competence and motivational interviewing skills of practice nurses: A pre-test posttest control group study. J Adv Nurs 2014;70:2272-83. https://doi.org/10.1111/jan.12376.

[14] McKenny K. Using an online video to teach nursing skills. Teach Learn Nurs 2011;6:172-5. https://doi.org/10.1016/j.teln.2011.04.003.

[15] Salina L, Ruffinengo C, Garrino L, Massariello P, Charrier L, Martin B, et al. Effectiveness of an educational video as an instrument to refresh and reinforce the learning of a nursing technique: a randomized controlled trial. Perspect Med Educ 2012;1:67-75. https://doi.org/10.1007/s40037-012-0013-4.

[16] Wang VJ, Cheng YT, Liu D. Improving education: Just-in-time splinting video. Clin Teach 2016;13:183-6. https://doi.org/10.1111/tct.12394.

[17] Khatiban M, Sangestani G, Oshvandi K. Midwifery students' experience of role-playing as a teaching strategy: a qualitative study. J Nurs Educ 2014;3:70-8.

[18] Kumar M, Saxena I, Kumar J, Kumar G, Kapoor S. Assessment of lecture strategy with different teaching aids. J Clin Diagnostic Res 2015;9:CC01-5.

https://doi.org/10.7860/JCDR/2015/10805.5 413.

[19] Lindsay S, McDougall C, Sanford R, Menna-Dack D, Kingsnorth S, Adams T. Exploring employment readiness through mock job interview and workplace role-play exercises: Comparing youth with physical disabilities to their typically developing peers. Disabil Rehabil 2015;37:1651-63.

https://doi.org/10.3109/09638288.2014.973 968.

[20] Barratt J. Nurse Education in Practice A focus group study of the use of video-recorded simulated objective structured clinical examinations in nurse practitioner education. Nurse Educ Pract 2010;10:170-5. https://doi.org/10.1016/j.nepr.2009.06.004.

[21] Cardoso AF, Moreli L, Braga FTMM, Vasques CI, Santos CB, Carvalho EC. Nurse Education Today Effect of a video on developing skills in undergraduate nursing students for the management of totally implantable central venous access ports ㄴ. Nurse Educ Today 2012;32:709-13. https://doi.org/10.1016/j.nedt.2011.09.012.

[22] Schreiber BE, Junaid F, Fabiana G. Live lecture versus video podcast in undergraduate medical education. Med Educ 2010;10:1-6. https://doi.org/10.1186/1472-6920-10-68. 
[23] Mccutcheon K, Lohan M, Traynor M, Martin D. A systematic review evaluating the impact of online or blended learning vs. face-to-face learning of clinical skills in undergraduate nurse education. J Adv Nurs 2015;71:255-70. https://doi.org/10.1111/jan.12509.

[24] Missen K, McKenna L, Beauchamp A, Larkins JA. Qualified nurses' rate new nursing graduates as lacking skills in key clinical areas. J Clin Nurs 2016;25:2134-43.

https://doi.org/10.1111/jocn.13316.

[25] ZarifSanaiey N, Amini M, Saadat F. A comparison of educational strategies for the acquisition of nursing student's performance and critical thinking: Simulation-based training vs. integrated training (simulation and critical thinking strategies). BMC Med Educ 2016;16:17. https://doi.org/10.1186/s12909-016-08120 .

[26] Kalyan G, Vatsa M. Neonatal Nursing: An Unmet Challenge in India. Indian J Pediatr 2014;81:1205-11. https://doi.org/10.1007/s12098-014-1567-4.

[27] Haraldseid C, Friberg F, Aase K. Nursing students' perceptions of factors influencing their learning environment in a clinical skills laboratory: A qualitative study. Nurse Educ Today 2015;35:e1-6. https://doi.org/10.1016/j.nedt.2015.03.015.

[28] Zieber M, Sedgewick M. Competence, confidence and knowledge retention in undergraduate nursing students- $\mathrm{A}$ mixed method study. Nurse Educ Today 2018;62:1621.

https://doi.org/10.1016/j.nedt.2017.12.008.

[29] El-sayed REH, El-sayed SEAE. Video-based lectures: An emerging paradigm for teaching human anatomy and physiology to student nurses. Alexandria J Med 2013;49:215-22. https://doi.org/10.1016/j.ajme.2012.11.002.

[30] Mckenna L, Missen K, Cooper S, Bogossian F, Bucknall T, Cant R. Situation awareness in undergraduate nursing students managing simulated patient deterioration. Nurse Educ Today 2014:1-5. https://doi.org/10.1016/j.nedt.2013.12.013.

[31] Felton A, Royal J. Nurse Education in Practice Skills for nursing practice: Development of clinical skills in pre-registration nurse education. Nurse Educ Pract 2015;15:38-43. https://doi.org/10.1016/j.nepr.2014.11.009.

[32] Massey MG, Kim SH, Mitchell C. A study of the learning styles of undergraduate social work students. J Evid Based Soc Work 2011;8:294303.

https://doi.org/10.1080/15433714.2011.557 977.

[33] Gurpinar E, Alimoglu MK, Mamakli S, Aktekin M. Can learning style predict student satisfaction with different instruction methods and academic achievement in medical education? Am J Physiol - Adv Physiol Educ 2010;34:1926. https://doi.org/10.1152/advan.00075.2010. 